\title{
Surgical treatment of posttraumatic ankylosis of the TMJ with different pathogenic mechanisms
}

\author{
Timucin Baykul ${ }^{1}$ \\ Mustafa Asim Aydin² \\ Serdar Nazif Nasir ${ }^{3}$ \\ Orcun Toptas ${ }^{4}$
}

\begin{abstract}
Objective: Posttraumatic ankylosis of the TMJ can be caused by many different pathogenic mechanisms. Prosthetic alloplastic grafts and autogenous grafts are the options for surgical treatment.

Methods: Seven patients were examined clinically and radiologically. Autogenous interpositioners were used for treatment of TMJ ankylosis.

Results: No major complications were seen after surgery. Interincisal distances have significantly widened following mouth opening exercises for one year.

Conclusions: Human skulls have many structure and shape differences, so it is difficult to replace a jaw joint successfully with an artificial one. Using autogenous tissues seems an appropriate choice for treatment. (Eur J Dent 2012;6:318-323)
\end{abstract}

Key words: Ankylosis; TMJ; trauma

\section{INTRODUCTION}

The temporomandibular joint (TMJ) is the most active joint of the body. ${ }^{1}$ Limitations of the mouth opening can be caused by bony or fibrous ankylosis of the TMJ as a sequel to trauma, infection,

1 Department of Oral and Maxillofacial Surgery, Faculty of Dentistry, Suleyman Demirel University, Isparta, TURKIYE

2 Department of Plastic, Reconstructive and Aesthetic Surgery, Faculty of Medicine, Suleyman Demirel University, Isparta, TURKIYE

3 Department of Plastic, Reconstructive and Aesthetic Surgery, Hacettepe University, Ankara, TURKIYE

4 Department of Oral and Maxillofacial Surgery, Faculty of Dentistry, Abant Izzet Baysal University,

- Bolu, TURKIYE

Corresponding author: Dr. Orçun Toptas Abant Izzet Baysal Universitesi, Dishekimliği Fakultesi, Agiz, Dis ve Cene Cerrahisi AD., 14300 Bolu, TURKIYE Tel: +903742705353

Fax: +903742700066

Email: otoptasQibu.edu.tr autoimmune disease or failed surgery. ${ }^{2}$ It is a disabling condition of the masticatory system that alters eating habits and speech ability. ${ }^{3-5}$ Another result of the TMJ ankylosis is poor oral hygiene. Posttraumatic ankylosis can be caused by different pathogenic mechanisms such as organization and ossification of hematoma, maltreated facial fractures, systemic diseases such as ankylosing spondylitis, rheumatoid arthritis, psoriasis, and auto-immune disease that increases the effects of micro-trauma. ${ }^{2}$

Absence of an intact disc and articular surface damage are believed to be the most important factors in the development of TMJ ankylosis. It is confirmed that the presence of the disc prevents development of fibrous intra-articular ankylosis of the TMJ. ${ }^{6}$ Various surgical techniques have been described as more or less successful for treatment. ${ }^{7}$ 
The most frequent complications are re-ankylosis and limited range of mandibular movement. ${ }^{8}$ Gap arthroplasty, interpositional arthroplasty, and joint reconstruction with joint substitution are the most frequently reported operations. ${ }^{9}$ The basic treatment technique used on the fully-grown patient is condylectomy with gap arthroplasty. ${ }^{10}$

In this study, seven cases of posttraumatic ankylosis with emphasis on pathogenic mechanisms will be presented.

\section{MATERIALS AND METHODS}

The surgical operations and follow-up were carried out on seven subjects, aged between six and fifty-four years old. All surgical procedures were performed at Süleyman Demirel University Research Hospital in Isparta. More information about the subjects is shown in Table 1.

Four female and three male patients were operated on for TMJ ankylosis. The causes of ankylosis were trauma with different pathogenic mecha- nisms. Patients' major complaint was limited mouth opening. Three patients had trauma history during early childhood, and one of them had vascular necrosis on the right condyle due to possible long standing micro-trauma (Figures 1a, b, c). Only Patient 5 had bilateral ankylosis (Figures $2 a, b)$. Six patients had unilateral ankylosis and facial asymmetry due to an ankylotic TMJ side. Patients 2, 5 and 6 had ankylosis due to condylar fractures. Patient 2 and 6 had been operated on at other medical centers before, and patient 2 had a dislocated silastic implant.

All patients were evaluated before surgery with CT scans and conventional radiographs including orthopantomographs. All operations were performed under general anesthesia with nasotracheal intubation. No patients complained about the aesthetic problem with the preauricular approach. There was no permanent facial nerve damage and no case of Frey's syndrome. Mouth opening exercises were given to patients, and all patients were

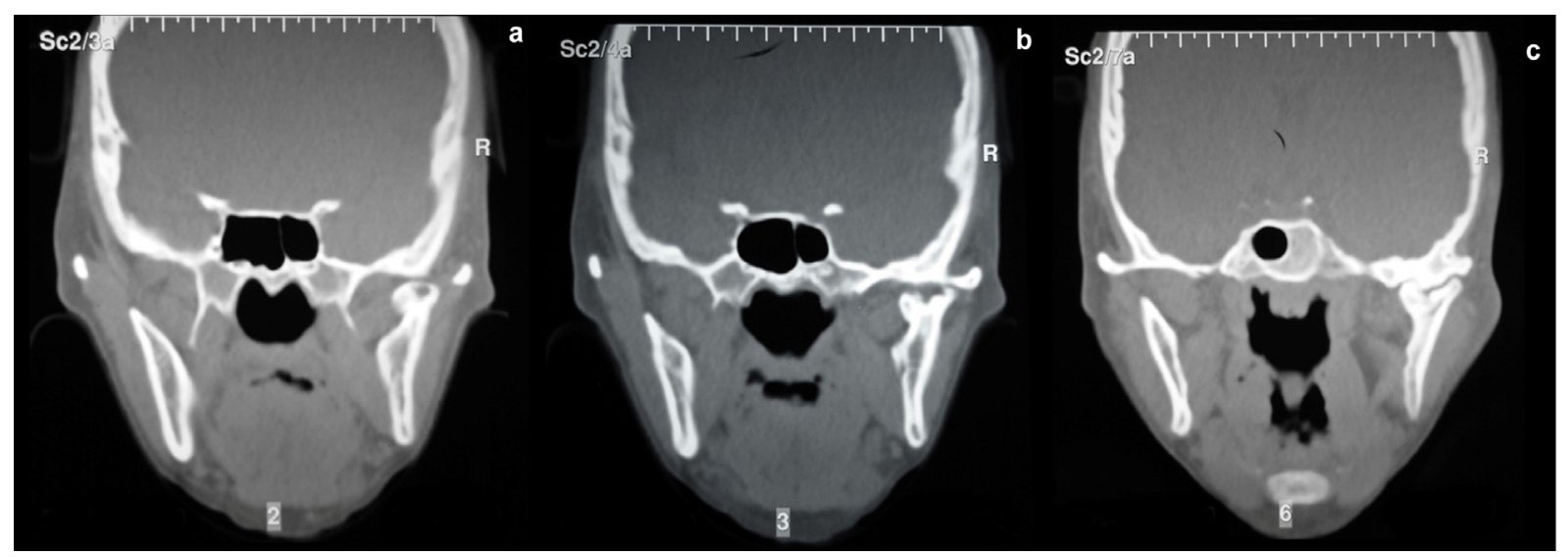

Figure 1a, b, c. Computed tomography views of the avascular necrosis on the right condyle of case 3.

Table 1. Clinical information of the patients.

\begin{tabular}{|c|c|c|c|c|c|c|c|c|}
\hline Patient & Age & Sex & Type of Ankylosis & Treatment & $\begin{array}{c}\text { Preoprative } \\
\text { interincisal } \\
\text { mouth opening }\end{array}$ & $\begin{array}{l}\text { Postoperative } \\
\text { interincisal } \\
\text { mouth opening }\end{array}$ & $\begin{array}{l}\text { Preoperative } \\
\text { symptoms }\end{array}$ & $\begin{array}{l}\text { Follow-up } \\
\text { period }\end{array}$ \\
\hline 1 & 44 & M & $\begin{array}{l}\text { Fibrous ankylosis due to } \\
\text { zygomatic arc attachment to coro- } \\
\text { noid process }\end{array}$ & $\begin{array}{l}\text { Zygomatic arch reduction and } \\
\text { temporal fascial flap }\end{array}$ & $12 \mathrm{~mm}$ & $37 \mathrm{~mm}$ & $\begin{array}{l}\text { mouth opening } \\
\text { limitation }\end{array}$ & 24 months \\
\hline 2 & 54 & $\mathrm{~F}$ & $\begin{array}{l}\text { Condylar facture and } \\
\text { reankylosis after unsuccessful } \\
\text { alloplastic implant treatment }\end{array}$ & $\begin{array}{l}\text { Gap arthroplasty and costal cartilage } \\
\text { interpositioner }\end{array}$ & $9 \mathrm{~mm}$ & $41 \mathrm{~mm}$ & $\begin{array}{l}\text { mouth opening } \\
\text { limitation } \\
\text { pain swelling }\end{array}$ & 24 months \\
\hline 3 & 17 & $\mathrm{~F}$ & $\begin{array}{l}\text { Avascular necrosis due to possible } \\
\text { long standing micro-trauma. }\end{array}$ & $\begin{array}{l}\text { Gap arthroplasty and temporal } \\
\text { fascial flap }\end{array}$ & $15 \mathrm{~mm}$ & $35 \mathrm{~mm}$ & $\begin{array}{l}\text { mouth opening } \\
\text { limitation }\end{array}$ & 36 months \\
\hline 4 & 6 & M & $\begin{array}{l}\text { Postnatal ankylosis due to difficult } \\
\text { labour with forceps. }\end{array}$ & $\begin{array}{c}\text { Gap arthroplasty and costal cartilage } \\
\text { interpositioner }\end{array}$ & $11 \mathrm{~mm}$ & $30 \mathrm{~mm}$ & $\begin{array}{l}\text { mouth opening } \\
\text { limitation }\end{array}$ & 36 months \\
\hline 5 & 45 & M & $\begin{array}{l}\text { Ankylotic block formations due to } \\
\text { condylar fractures bilaterally. }\end{array}$ & $\begin{array}{c}\text { Gap arthroplasty and costal cartilage } \\
\text { interpositioner }\end{array}$ & $14 \mathrm{~mm}$ & $40 \mathrm{~mm}$ & $\begin{array}{l}\text { mouth opening } \\
\text { limitation }\end{array}$ & 24 months \\
\hline 6 & 31 & $\mathrm{~F}$ & $\begin{array}{c}\text { Fibrous ankylosis due to childhood } \\
\text { facial trauma and unsuccessful } \\
\text { treatment attempt. }\end{array}$ & $\begin{array}{c}\text { Gap arthroplasty and costal cartilage } \\
\text { interpositioner }\end{array}$ & $17 \mathrm{~mm}$ & $35 \mathrm{~mm}$ & $\begin{array}{l}\text { mouth opening } \\
\text { limitation } \\
\text { laterognathia }\end{array}$ & 36 months \\
\hline 7 & 7 & $\mathrm{~F}$ & $\begin{array}{l}\text { Extra bone formation at the } \\
\text { lateral side of TMJ due to trauma. }\end{array}$ & Removal of extra bone structure. & $12 \mathrm{~mm}$ & $43 \mathrm{~mm}$ & $\begin{array}{c}\text { mouth opening } \\
\text { limitation } \\
\text { facial assymetry in } \\
\text { zygomatic arc region }\end{array}$ & 48 months \\
\hline
\end{tabular}


followed up with for at least two years (See Figures $3 a, b)$. Preoperative and postoperative interincisal distances were remarkably different, and the longterm follow-up results were satisfying. No re-ankylosis occurred by the end of the second year.

\section{DISCUSSION}

After acute disorders had been ruled out, the clinical diagnosis of all cases was ankylosis. Trau$\mathrm{ma}$ is the most common etiologic factor of TMJ ankylosis. ${ }^{11}$ TMJ trauma has been documented as a major etiologic factor in $86 \%$ of cases caused by the unilateral or bilateral condylar fractures. $10 \mathrm{It}$ has been reported that $85.7 \%$ of TMJ ankylosis is associated with trauma. ${ }^{12}$ In our study, trauma was the only cause of TMJ ankylosis.

Because of technical difficulties and recurrence, management of TMJ ankylosis poses a challenge. TMJ ankylosis occurs in both children and adults. In children, involvement of postoperative development of the mandible causes more problems, resulting in maxillofacial deformity such as facial asymmetry, micrognathia or bird face deformity, and malocclusion. ${ }^{9,13}$ An intracapsular compression fracture or a suppurative arthritis of mid- dle ear infection can cause ankylosis in children. ${ }^{4}$ Today's routinely applied antibiotics for middle ear otitis and better surgical treatments of fractures of the mandibular condyle may decrease the incidence of TMJ ankylosis. ${ }^{7}$ Trauma, generally due to traffic accidents, is the most common reason for TMJ ankylosis, with a frequency reported between 29 and 100\%. ${ }^{8}$ Traumatic TMJ ankylosis development mechanisms are still unclear. ${ }^{2}$

Posttraumatic ankylosis may occur by different pathogenic mechanisms. Injuries may cause intra-capsular condylar fractures, hemarthrosis and secondary hematoma organization with ensuing ankylotic block formation. ${ }^{14}$ Also untreated zygomatic arc fractures or previous TMJ surgery may be the cause of TMJ ankylosis. Micro-trauma can be the etiologic factor by producing local inflammation or avascular necrosis, especially in the presence of a systemic disease like sicklecell anaemia. Organization and ossification of an intracapsular hematoma following TMJ injury is a popular hypothesis for explaining the mechanism of the traumatic TMJ ankylosis. ${ }^{2}$

The second hypothesis explains the phenomena due to sagittal fracture of mandibular con-

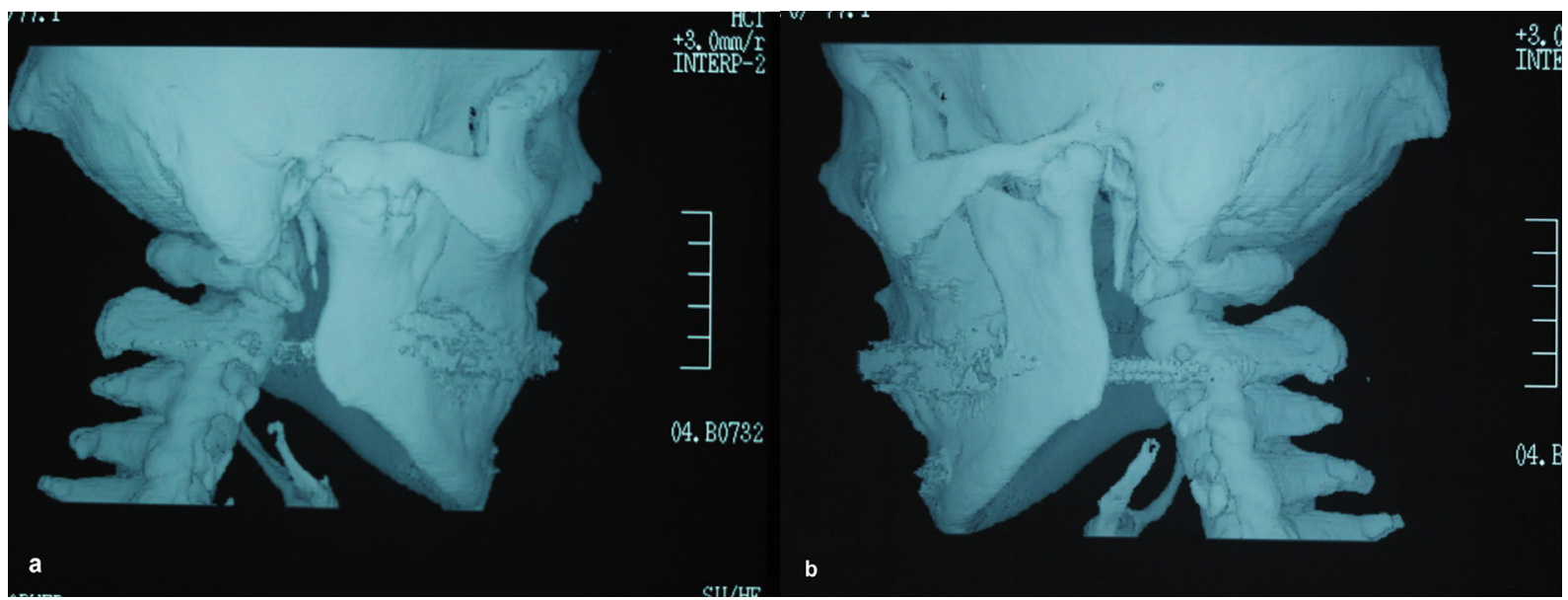

Figure 2a, b. 3-D computed tomography views of case 5. Ankylotic segments can be seen bilaterally.
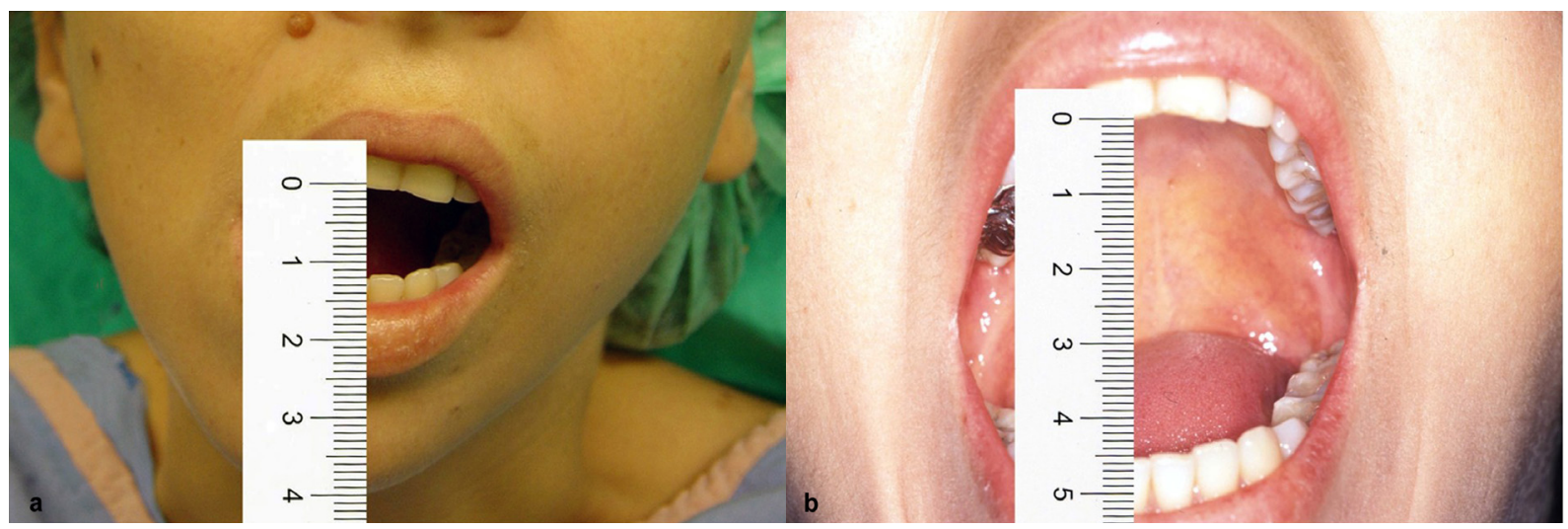

Figure 3a, b. Pre-operative and post-operative mouth opening of the case 3 (Postoperative mouth opening one year after surgery). 
dyle. After trauma, sagittal fracture occurs at the mandibular condyle. The fragment of sagittal fracture of mandibular condyle is usually pushed anteriorly and medially through the lateral pterygoid muscle. ${ }^{15}$ A distraction osteogenesis occurs in the fracture healing process. Eventually, the TMJ ankylosis is formed..$^{13}$ In this study, Patient 7 had a trauma when she was four years old, and her mouth opening had decreased day by day for three years. CT scans revealed a mandibular bone formation at the lateral side of TMJ. The insufficient follow-up after condylar fractures can cause TMJ ankylosis. ${ }^{16}$ By reason of slow ankylosis completion, the second hypothesis mentioned above seems suitable for this case.

According to the hypothesis, despite the extra bone structure that must have been at the medial side, in our case it was seen at the lateral side. It was thought that only a mandibular bone segment had attached to TMJ, as in Case 1. Patient 1 had unilateral TMJ ankylosis due to untreated dislocated multiple facial fractures and attached zygomatic arc to the coronoid process. The patient's history revealed that no exercises had been performed for two months after intermaxillar fixation. Considering only jaw fracture and ignoring the other facial fractures may cause more problems, as was seen in our patient.

There is no unanimous agreement on the treatment of ankylosis of TMJ. Two options are available and popular: prosthetic implants and autogenous grafts. Proplast-Teflon TMJ implants were popular until 1990. After 1990, it has been established that implants cause a foreign body giant cell reaction, and the US Food and Drug Administration issued a nation-wide safety alert. ${ }^{17,18}$ The prosthetic systems that are currently available are generally "ball and socket" types consisting of the condylar (mandibular) implant, the fossa implant, and the screws.

If large-sample studies demonstrate the superiority of total TMJ replacement over less invasive treatment methods, prosthetic replacement may be a viable option for TMJ ankylosis. ${ }^{1}$ Alloplasts have their advantages, such as avoiding donor site morbidity, reducing operation time, reducing the chance of recurrent ankylosis, and allowing a closer reproduction of the normal anatomy of the joint. They also have some disadvantages like displacement, failure and fracture of the prosthesis, infection and extrusion. ${ }^{17,19-21}$ Prosthetic replacement of the TMJ is expensive, and there may be serious consequences. Some guidelines for prosthetic replacement operations should be devel- oped. ${ }^{22}$ Prosthetic replacement systems tend to be allergic and can cause foreign-body giant cell reactions. ${ }^{23,24}$ The long-term results of 48 patients after TMJ disc removal and replacement by a silicone sheet revealed that, the implants had to be removed after an average 5.6 years for eight patients. No statistically significant improvement in joint function was observed in five of the eight. ${ }^{25}$

Autogenous TMJ reconstruction materials such as clavicle, fibula, costochondral and iliac grafts were developed. ${ }^{17}$ The disadvantages of autogenous reconstruction are: (1), limited augmentation of ramus height; (2), extra donor site morbidity; and (3), unpredictable resorption or growth rate..$^{21,26}$ The controversy continues between alloplastic reconstruction and autogenous reconstruction. ${ }^{17}$ In our cases, the appropriate treatment method was decided on a case-by-case basis, and the preferred method of reconstruction was autogenous replacement. We haven't seen any important complications due to autogenous grafts.

Using costochondral graft for reconstruction of temporomandibular joints were described by Gillies in 1920. ${ }^{27}$ Costochondral graft has biologic and anatomical similarities to the mandibular condyle. Complications at the donor site are rare. Rib regeneration generally is completed within a year. ${ }^{27,28}$ Encouraging functional and cosmetic results have been reported..$^{29,30}$ In our study, autogenous costochondral graft was used in four cases. Costochondral grafts have several advantages. Cartilaginous articulating surface mimics the normal condyle and also has adapting, remodelling, and fusing ability to the ramus. Vascularised recipient bed and correct graft length maximises the chance of survival of the graft. ${ }^{27}$ In this limited series of cases, it appears that costochondral graft is suitable interpositional material for TMJ, and after the surgical operation, ramus height remains good. The risk of complications at the donor site seems low.

Aggressive resectioning of bony or fibrous tissues in the medial aspect of the TMJ is necessary. The temporalis muscle and fascia flap have been widely used in TMJ ankylosis. The advantages of this technique are: (1), autogeneity; (2), resilience; (3), adequate blood supply; and (4), proximity to the joint, which allows a pedicled transfer of vascularized tissue into the joint area. ${ }^{12,31}$ It can be a valuable option after previous unsuccessful alloplastic treatments. ${ }^{32}$ Patient 1 had a successful operation and has not any important complications due to temporal fascial flap. 


\section{CONCLUSIONS}

The causes of TMJ ankylosis are generally traumatic. Traumatic ankylosis has many pathogenic mechanisms. A clinician should examine and evaluate the patient totally. After trauma, ignoring the structural disintegration of facial bones may cause TMJ ankylosis.

The surgical treatment method depends on each surgeon's choice and experience. It is difficult to replace a jaw joint successfully with artificial one because of the natural variations in human skull shapes and structures. When the surgery is performed carefully, atraumatic, autogenous interpositioners show great results.

\section{REFERENCES}

1. Guarda-Nardini L, Manfredini D, Ferronato G. Temporomandibular joint total replacement prosthesis: current knowledge and considerations for the future. Int $J$ Oral Maxillofac Surg 2008;37:103-110.

2. Guven 0. A clinical study on temporomandibular joint ankylosis. Auris Nasus Larynx 2000;27:27-33.

3. Zhi K, Ren W, Zhou H, Gao L, Zhao L, Hou C, Zhang Y. Management of temporomandibular joint ankylosis: 11 years' clinical experience. Oral Surg Oral Med Oral Pathol Oral Radiol Endod 2009;108:687-692.

4. Guven 0. A clinical study on temporomandibular joint ankylosis in children. J Craniofac Surg 2008;19:1263-1269.

5. Sporniak-Tutak K, Janiszewska-Olszowska J, Kowalczyk R. Management of temporomandibular ankylosis--compromise or individualization--a literature review. Med Sci Monit 2011;17:RA111-116.

6. Miyamoto H, Kurita K, Ogi N, Ishimaru JI, Goss AN. The role of the disk in sheep temporomandibular joint ankylosis. Oral Surg Oral Med Oral Pathol Oral Radiol Endod 1999;88:151-158.

7. Gundlach KK. Ankylosis of the temporomandibular joint. J Craniomaxillofac Surg 2010;38:122-310.

8. Miyamoto H, Kurita K, Ogi N, Ishimaru JI, Goss AN. Effect of limited jaw motion on ankylosis of the temporomandibular joint in sheep. Br J Oral Maxillofac Surg 2000;38:148-153.

9. Li Z, Li ZB, Li JR. Surgical management of posttraumatic temporomandibular joint ankylosis by functional restoration with disk repositioning in children. Plast Reconstr Surg 2007;119:1311-1316.

10. Roychoudhury A, Parkash H, Trikha A. Functional restoration by gap arthroplasty in temporomandibular joint ankylosis: a report of 50 cases. Oral Surg Oral Med Oral Pathol Oral Radiol Endod 1999;87:166-169.
11. Bello SA, Aluko Olokun B, Olaitan AA, Ajike SO. Aetiology and presentation of ankylosis of the temporomandibular joint: report of 23 cases from Abuja, Nigeria. Br J Oral Maxillofac Surg 2012;50:80-84.

12. Su-Gwan K. Treatment of temporomandibular joint ankylosis with temporalis muscle and fascia flap. Int J Oral Maxillofac Surg 2001;30:189-193.

13. Meng FW, Zhao JL, Hu KJ, Liu YP. A new hypothesis of mechanisms of traumatic ankylosis of temporomandibular joint. Med Hypotheses 2009;73:92-93.

14. Valentini V, Vetrano S, Agrillo A, Torroni A, Fabiani F, Iannetti G. Surgical treatment of TMJ ankylosis: our experience (60 cases). J Craniofac Surg 2002;13:59-67.

15. Liu CK, Liu P, Meng FW, Deng BL, Xue Y, Mao TQ, Hu KJ. The role of the lateral pterygoid muscle in the sagittal fracture of mandibular condyle (SFMC) healing process. $\mathrm{Br} J$ Oral Maxillofac Surg 2012;50:356-360, Epub 2011 Jul 29.

16. Koumoura F, Papakosta V. A serious complication in the temporomandibular region due to insufficient follow-up. Orthodontics (Chic.) 2011;12:134-139.

17. Abramowicz S, Dolwick MF, Lewis SB, Dolce C. Temporomandibular joint reconstruction after failed teflon-proplast implant: case report and literature review. Int J Oral Maxillofac Surg 2008;37:763-767.

18. Kearns GJ, Perrott DH, Kaban LB. A protocol for the management of failed alloplastic temporomandibular joint disc implants. J Oral Maxillofac Surg 1995;53:1240-1247; discussion 1248-1249.

19. Wolford LM, Cottrell DA, Henry CH. Temporomandibular joint reconstruction of the complex patient with the Techmedica custom-made total joint prosthesis. J Oral Maxillofac Surg 1994;52:2-10; discussion 11.

20. Saeed N, Hensher R, McLeod N, Kent J. Reconstruction of the temporomandibular joint autogenous compared with alloplastic. Br J Oral Maxillofac Surg 2002;40:296-299.

21. Karaca C, Barutcu A, Baytekin C, Yilmaz M, Menderes A, Tan O. Modifications of the inverted T-shaped silicone implant for treatment of temporomandibular joint ankylosis. J Craniomaxillofac Surg 2004;32:243-246.

22. Sidebottom AJ. Guidelines for the replacement of temporomandibular joints in the United Kingdom. Br J Oral Maxillofac Surg 2008;46:146-147.

23. Speculand B. Current status of replacement of the temporomandibular joint in the United Kingdom. Br J Oral Maxillofac Surg 2009;47:37-41.

24. Sidebottom AJ, Speculand B, Hensher R. Foreign body response around total prosthetic metal-on-metal replacements of the temporomandibular joint in the UK. Br J Oral Maxillofac Surg 2008;46:288-292. 
25. Schliephake $H$, Schmelzeisen R, Maschek $H$, Haese M. Long-term results of the use of silicone sheets after diskectomy in the temporomandibular joint: clinical, radiographic and histopathologic findings. Int J Oral Maxillofac Surg 1999;28:323-329.

26. Guven 0. Treatment of temporomandibular joint ankylosis by a modified fossa prosthesis. J Craniomaxillofac Surg 2004;32:236-242.

27. Medra AM. Follow up of mandibular costochondral grafts after release of ankylosis of the temporomandibular joints. Br J Oral Maxillofac Surg 2005;43:118-122.

28. Lindqvist C, Pihakari A, Tasanen A, Hampf G. Autogenous costochondral grafts in temporo-mandibular joint arthroplasty. A survey of 66 arthroplasties in 60 patients. J Maxillofac Surg 1986;14:143-149.

29. Ross RB. Costochondral grafts replacing the mandibular condyle. Cleft Palate Craniofac J 1999;36:334-339.

30. Singh V, Verma A, Kumar I, Bhagol A. Reconstruction of ankylosed temporomandibular joint: Sternoclavicular grafting as an approach to management. Int J Oral Maxillofac Surg 2011;40:260-265.

31. Clauser L, Curioni C, Spanio S. The use of the temporalis muscle flap in facial and craniofacial reconstructive surgery. A review of 182 cases. J Craniomaxillofac Surg 1995;23:203-214

32. Smith JA, Sandler NA, Ozaki WH, Braun TW. Subjective and objective assessment of the temporalis myofascial flap in previously operated temporomandibular joints. J Oral Maxillofac Surg 1999;57:1058-1065; discussion 1065-1057. 